\title{
Barrier therapies supporting the biology of the mucosal barrier- medical devices for common clinical mucosal disorders
}

\author{
Ricky W. McCullough \\ Translational Medicine Clinic and Research Center at Storrs, Storrs, CT, USA \\ Correspondence to: Ricky W. McCullough, MD, ScM, FAcadTM. Translational Medicine Clinic and Research Center at Storrs, Storrs, CT 06268, \\ USA. Email: rwmmd@muellermedical.com.
}

\begin{abstract}
Recently mucosal barrier therapies have been either CE marked or licensed by Food and Drug Administration (FDA) as medical devices. A barrier therapy (BT) uses a physical non-drug mode of action as its sole mechanism to manage a clinical syndrome. A BT is verified as technically or biologically safe having efficacy that has been proven by valid clinical trials. However, it remains unclear what anatomical portions of the mucosa are physically engaged by any given BT. Therefore, this article clarifies the physical basis for clinical efficacy of any given mucosal BT's. Current regulatory classification of medical devices is defined. More importantly, the biology of mucosal barrier is detailed by structure, compartmental elements and function. A live-function or cross-sectional anatomical perspective of the mucosa is provided. A crosssectional anatomical perspective of the mucosa is provided in order to highlight the physical point of contact for any given mucosal BT's. Five traits of an effective mucosal BT are proposed to assess traits of fitness for any given BT. A BT is either classical, possessing four to five traits, or non-classical, possessing three or fewer traits. Among 16 commercially available mucosal BT's which share nine distinct formulations, most are non-classical BT while two (alginate and polymeric sucralfate) are classical mucosal BT's.
\end{abstract}

Keywords: Barrier therapy (BT); medical device; mucosal barrier; alginate; polymeric sucralfate

Received: 12 August 2019; Accepted: 18 January 2020; Published: 05 January 2021.

doi: $10.21037 / \operatorname{tgh} .2020 .02 .02$

View this article at: http://dx.doi.org/10.21037/tgh.2020.02.02

\section{Introduction}

Structural integrity and functional homeostasis are the principal roles of the mucosal barrier. This is true for the mucosa of the oral cavity, nasopharynx, lungs, gastrointestinal tract (GIT) and urogenital tract. Barrier therapies support the biology of the mucosal barrier through physical engagement of the mucosal lining accessible from the lumen or cavity it lines. Common clinical syndromes stem from structural breaches and/or immuno-mediated compromises of functional homeostasis within the mucosal lining. In the oropharynx and GIT clinical syndromes are characterized by pain, nausea, vomiting, ileus, constipation, diarrhea and sometimes mucosal bleeding. These symptoms and signs indicate a breach of the mucosa and the initiation of processes to eliminate offending factors and to mend the breach. Maintenance of structural and functional integrity is internally controlled and localized to the mucosa. Accordingly, the biology of the mucosal barrier is defined by elements that secure its integrity (1-6) and functional immuno-homeostasis $(7,8)$ and its many mechanisms of functional homeostasis. Functional homeostasis involves continuous immuno-neuronal surveillance using a system of cells that have capacity to sample, recognize, tolerate, attack or recall prior antigenic events in anticipation of future ones (7-11). In the oropharynx and GIT, these efforts to maintain mucosal integrity are conducted in the background of the mucosa's main function to process, digest and assimilate food and drink. Thus, the GIT mucosal barrier conducts a duality of operations-vigilant maintenance and food assimilation.

Barrier therapies are short term interventions providing transient but meaningful support to mucosal integrity. Mucosal integrity involves protected continuation of 
functional mucosal homeostasis. The clinical excellence of a barrier therapy (BT) rests on the quality of symptomatic relief and the rapidity and extent of associated healing beneath the therapeutic barrier. This latter trait-the rapidity and extent of physiologic healing beneath the therapeutic barrier - is indeed a measure of barrier quality. By mending the initial breach near the luminal surface, high quality barrier therapies restore the biological function of compromised mucosa.

A healthy mucosal barrier protects underlying tissues from toxins, irritants, pathogens and effluents coursing through lumens and body cavities lined by mucosa. In the oropharynx and GIT, the collapse of structural integrity and disruption of mucosal immuno-homeostasis is depicted in clinical conditions such as gingivitis, peri-implant mucositis, oral lichen planus, stomatitis, chemoradiation mucositis, esophagitis, gastrointestinal mucositis, gastroesophageal reflux disorder, both erosive gastroesophageal reflux disease (GERD) and non-erosive reflux disease (NERD), colonic mucositis, ulcerative colitis, pouchitis and radiation proctitis. Each condition is an inflammatory breach of the mucosal barrier. There is the functional loss of integrity between juxtacellular layer (mucin compartment near the lumen/cavity) and cellular layer (the epithelium). As will be discussed, the overall integrity of underlying mucosal compartments is consummated in maintaining a functional and unperturbed mucus gel compartment $(12,13)$.

This review describes the biology of the mucosal barrier and the medical device therapies design to manage clinical syndromes caused by breaches within the mucosal barrier. The biology of the mucosal barrier will be addressed as a narrative on compartmental, structural and operational functions. Operational functions of the biological barrier will be presented in a cross-sectional perspective, slicing through each compartment to illustrate the dynamism of a healthy mucosal barrier and the layered operations protected by the overlying blanket of mucus gel. The mucus gel is the physiological target or 'ground zero' for barrier therapies. Thus, based on this notion of targeted action, there are at least five common characteristics that establish a clinical standard of fitness by which barrier therapies may be assessed. This clinical standard of fitness discerns barrier therapies to be either classical or non-classical, depending on the number of characteristics a therapy possesses to satisfy fitness.

Understanding the structural biology (and dynamism) of the healthy mucosal barrier provides a useful context to review therapies designed to support the mucosa and manage syndromes resulting from its breach. It is appropriate, initially, to provide background on the regulatory approach to barrier therapies by the United States Food and Drug Administration (US FDA) and the European Medicines Agency (EMA). This then, is followed by a discussion on the biology of the healthy mucosal barrier in the oropharynx and GIT (structure, function \& dynamism), and subsequently closes with an examination of current barrier therapies, both classical and non-classical ones.

\section{Regulatory approach}

\section{US FDA and the EMA}

The US FDA defines a medical device as any contrivance intended for use in diagnosis, cure, mitigation, treatment or prevention of disease or other conditions intended to affect the structure or function of the body and does not achieve its primary intended purposes through chemical action within or on the body and which is not dependent upon being metabolized for the achievement if any of its primary intended purpose (14). The EMA concurring with this definition, is somewhat more granular in its definition of medical device, stating that a medical device may contain an ancillary medicinal substance to support the proper functioning of the device, all such products falling under the medical device legislation must be CE marked (15). Going further the EMA states that some medical devices are made of substances that are absorbed by the human body to achieve their intended purpose (15), a characteristic of medical devices generally not accepted by the US FDA since absorption by the human body is regarded as being metabolized to achieve the device's primary purpose.

Despite these distinctions the chief overlap of the two regulatory bodies is that a medical device is for the diagnosis, treatment, mitigation of disease achieving this intended purpose by means of a physical mode of action largely free of a chemical action upon or within the body.

Barrier therapies have a greater use in the European Union influenced nations than in the United States. This report examines the concept of BT by reviewing the physiology of the biological barrier assisted by these therapies, the anatomical target of these therapies and the appropriateness of CE mark assignment.

\section{Device classification}

Regulatory classification of a medical device is dependent on whether the device is passive or active, for temporary, short 
Table 1 Regulatory classification of medical devices

\begin{tabular}{|c|c|c|c|c|c|c|c|c|c|}
\hline \multirow[b]{2}{*}{ Type of device } & \multicolumn{3}{|c|}{ Temporary use } & \multicolumn{3}{|c|}{ Short-term use } & \multicolumn{3}{|c|}{ Long term use } \\
\hline & $\begin{array}{l}\text { Skin, } \\
\text { cavity or } \\
\text { tract }\end{array}$ & $\begin{array}{l}\text { Traumatic } \\
\text { tissue }\end{array}$ & $\begin{array}{l}\text { Peripheral or } \\
\text { central blood } \\
\text { circulation }\end{array}$ & $\begin{array}{l}\text { Skin, cavity } \\
\text { or tract }\end{array}$ & $\begin{array}{c}\text { Traumatic } \\
\text { tissue }\end{array}$ & $\begin{array}{l}\text { Peripheral or } \\
\text { central blood } \\
\text { circulation }\end{array}$ & $\begin{array}{l}\text { Skin, cavity } \\
\text { or tract }\end{array}$ & $\begin{array}{l}\text { Traumatic } \\
\text { tissue }\end{array}$ & $\begin{array}{l}\text { Peripheral or } \\
\text { central blood } \\
\text { circulation }\end{array}$ \\
\hline \multicolumn{10}{|l|}{ Passive devices } \\
\hline $\begin{array}{l}\text { Medical/medicinal } \\
\text { barrier dressings }\end{array}$ & 1 & 2 & 2 & 1 & 2 & 2 & NA & NA & NA \\
\hline $\begin{array}{l}\text { Disposable aseptic } \\
\text { surgical devices }\end{array}$ & 1 & 2 & 3 & 2 & 3 & 3 & 2 & 3 & 3 \\
\hline $\begin{array}{l}\text { Container for } \\
\text { pharmaceutical liquid }\end{array}$ & 2 & 2 & 3 & 2 & 2 & 3 & 2 & 3 & 3 \\
\hline Implantable & NA & NA & NA & NA & NA & NA & 3 & 3 & 3 \\
\hline Contraceptive device & 2 & 2 & 3 & 2 & 3 & 3 & 3 & 3 & 3 \\
\hline \multicolumn{10}{|l|}{ Active devices } \\
\hline $\begin{array}{l}\text { Device for diagnostic } \\
\text { monitoring }\end{array}$ & & 2 & & & 2 & & & 3 & \\
\hline $\begin{array}{l}\text { Device for treatment } \\
\text { using energy source }\end{array}$ & & 2 & & & 2 & & & 3 & \\
\hline $\begin{array}{l}\text { Device using ionized } \\
\text { radiation }\end{array}$ & & 2 & & & 3 & & & 3 & \\
\hline
\end{tabular}

term or long term use and whether the device is in contact with skin, with a body cavity or tract, with traumatized tissue or with the peripheral or central blood circulation. According to Annex 9 Directive 93/42/EEC amendment concerning medical devices (16), transient or temporary means continuous use for less than 60 minutes; short term means continuous use for not more than 30 days and long term means continuous use for more than 30 days. Table 1 provides a general view of classification of medical devices. Barrier therapies discussed in this review are Class II and Class III medical devices intended as medicinal dressings for the mucosal barrier.

\section{Biology of the mucosal barrier in oropharynx and GIT}

The biology of the mucosal barrier has both structural and dynamic elements that define barrier integrity. In health the structure is of three compartments engaged in at least seven functions to maintain homeostasis. These structural elements are formed for function. The coordinated operations of functional elements speak to the dynamism of a healthy biological barrier. The dynamic operation of each structural element is maintained by the fidelity of the mucus gel. In addition to executing its own humoral role for mucosal homeostasis, the mucus gel is uniquely tasked with maintaining physical fidelity of the barrier, fidelity that is monitored by the cytosol of both epithelial cells and goblet cells utilizing their respective transmembrane mucins that pierces through the mucin gel. Effective barrier therapies structurally assist the mucus gel in maintaining physical fidelity.

\section{The structure of a bealthy biological barrier-tbree compartments—seven functions}

The biological barrier of the oropharynx and GIT could be divided into three histological compartments, each functionalized by cellular and non-cellular elements all coordinated and engaged in at least seven barrier functions. The precise sequence of interplay between sectional elements are still under study, yet sufficient information exists to provide a broad-brush understanding of the mucosal barrier and healthy functional homeostasis.

As shown in Table 2, the three histological compartments of the mucosal barrier include the mucin compartment, a single-cell epithelial compartment and the sub-epithelial 
Table 2 Structural biology and function of a healthy mucosal barrier

\begin{tabular}{|c|c|c|c|}
\hline $\begin{array}{l}\text { Barrier } \\
\text { compartments }\end{array}$ & Barrier functions & Functional \& cellular elements & References \\
\hline \multirow[t]{2}{*}{ Mucins } & I. Cover, capture, deflect, remove & $\begin{array}{l}\text { Loose mucin labyrinth, sterile dense adherent mucin, mucin } \\
\text { transient }\end{array}$ & $(1,4-6)$ \\
\hline & II. Neutralize and preserve & $\begin{array}{l}\text { Neutralize using IgA, anti-microbial agents; preserve } \\
\text { epithelium using trefoil factors (TFF1, TFF2, TFF3) }\end{array}$ & $(13,17-25)$ \\
\hline \multirow[t]{2}{*}{$\begin{array}{l}\text { Single cell } \\
\text { epithelium }\end{array}$} & $\begin{array}{l}\text { III. Antigen \& non-antigen } \\
\text { surveillance, detection, barrier } \\
\text { lubrication \& sustenance }\end{array}$ & $\begin{array}{l}\text { Sample surveillance by } \alpha \beta-I E L, \delta \gamma-I E L, M-c e l l s \text {, dendritic } \\
\text { cells, goblet cells; detect mucin disturbance by epithelial } \\
\text { transmembrane mucin; lubricate and sustain epithelium by } \\
\text { goblet cells producing mucin, trefoil factors; tuft cells and } \\
\text { enteroendocrine cells. }\end{array}$ & $(1-6,9,10,18,19,26-36)$ \\
\hline & $\begin{array}{l}\text { IV. Cap and close off luminal } \\
\text { contents }\end{array}$ & $\begin{array}{l}\text { Epithelial cells with toll-like receptors, tight junctions, } \\
\text { epithelial cytokine production, apical transmembrane mucin } \\
\text { \& cytosol signaling, basolateral growth factors }\end{array}$ & $(1,18,37-44)$ \\
\hline \multirow{3}{*}{$\begin{array}{l}\text { Lamina propria } \\
\text { and submucosa to } \\
\text { subserosa }\end{array}$} & V. Pre-emptive immune actions & $\begin{array}{l}\text { ILC-class I, II, III interacting with epithelial cells, IEL's, } \\
\text { goblet cells, dendritic cells, M-cells }\end{array}$ & $(7,11,30,45-47)$ \\
\hline & $\begin{array}{l}\text { VI. Adaptive counter-attack } \\
\text { immune actions }\end{array}$ & $\begin{array}{l}\text { Monocytes, macrophages, mast cells, B-lymphocytes, } \\
\text { T-lymphocytes, inflammasome formation }\end{array}$ & $(7,17,31,45,48,49)$ \\
\hline & $\begin{array}{l}\text { VII. Host warning and eliminate } \\
\text { effluent }\end{array}$ & $\begin{array}{l}\text { Enteric glial neurons with } 2 \text { classes of voltage-gated } \\
\text { receptors (ASIC, TRPV) on afferent neurons, with input to } \\
\text { efferent neurons that are responsive to cytokine secretions } \\
\text { from IEL, epithelial cells, mast cells and ILC's; these neurons } \\
\text { extend from the epithelial cell layer (including tuft cells and } \\
\text { enteroendocrine cells) downward into the submucosal plexus } \\
\text { and myenteric plexus, with functions for sensory, epithelial, } \\
\text { vascular, pain, nausea, emesis and motility }\end{array}$ & $(50-65)$ \\
\hline
\end{tabular}

IEL, intra-epithelial lymphocytes; ILC, immune lymphoid cells; ASIC, acid sensing ion channels; TFF, trefoil factors; TRPV, transient receptor potential vanilloid.

compartment or lamina propria (1). There are at least seven barrier functions conducted across these three histological compartments; they include (I) functions to cover, capture, deflect then remove; (II) functions to neutralize offenders and preserve physical epithelial cover; (III) functions of antigen and non-antigen surveillance, detection, barrier lubrication and sustenance; (IV) functions to cap and close out luminal contents using tight cell to cell attachment proteins; (V) pre-emptive immune activity by innate immune cells; (VI) counterattack pro-inflammatory actions of the adaptive immune cells; and (VII) functions that warn host through the enteric nervous system and secretory chemosensor cells that can initiate rapid (cathartic) elimination (expelling) of offending luminal contents.

\section{The mucin compartment-two distinct mucus layers and humoral components}

The mucin compartment is comprised of two distinct mucus layers that have a rapid turnover. It is estimated that the mucus gel is replaced at least 17.8 times per 24 hours, being calculated comparatively from the rate of mucus turnover in the rat (66-68) which in turn is correlated to the human GIT (69). Between 5 to 7 liters of water and mucus is secreted into the GIT daily (70) with the majority of water later reabsorbed from the lumen. Mucin are glycoproteins comprised of more than $80 \%$ carbohydrate (71), having a linear protein structure covalently bonded to branched glycans at the hydroxyl group of threonine and serine, giving the mucin compound a bristled bottle-brush appearance. Branched glycans are distributed along protein strands possessing cysteine-rich domains that permit intermolecular bonding between mucin molecules so as to form dimeric and multimeric mucin. Multimeric mucin is then packed through hydrogen bonding into mucin networks with varying degrees of hydration. Containing large amounts of water covert mucin networks into gels. The glycans in gel 
forming mucins resist breakdown by digestive enzymes and function to structurally protect and lubricate the oropharynx and GIT. It is here where barrier therapies act to enhance the three dimensional structural integrity of mucin gel.

The first outermost layer of the mucin compartment is a soluble mucus layer (largely MUC2) containing commensal bacteria and barrier defense molecules originating from T-cells (IgA), from epithelial cells [releasing regenerating islet-derived protein-3 gamma (RegIII $\gamma), \beta$-defensins, cathelicidins], from goblet cells [releasing chloride channel accessory-1 protein (CLCA1), resistin-like molecule beta (RELM- $\beta$ ), zymogen granule membrane protein-16 (Zg16), anterior gradient-2 (Agr2)], and from colonic paneth cells [releasing $\alpha$-defensins, lysozyme, RegIII $\gamma$, secretory phospholipase type A-2 (sPLA2)] $(4,13,17)$. Beneath this outermost loose region of mucin is a second innermost stratum of mucin that is less soluble and more adherent (26) generally devoid of bacteria (6), accommodating transmembrane mucins that are interwoven into it. Proximally, transmembrane mucin is attached to the apical surface of the enteric epithelium having its mid-section and distal ends interwoven in the adherent mucin layer. Seven structurally distinct transmembrane mucins (MUC1, MUC3, MUC4, MUC12, MUC13, MUC16, MUC17) form the enterocyte glycocalyx which in turn are bound to apical membranes of goblet cells and epithelial enterocytes. Distal dangling ends of transmembrane mucins engaged in a mesh work of adherent MUC2 mucin form an adherent sterile minimally hydrated gel that act as an exclusionary electrostatic 'thicket' blanketing the underlying (multicellular) epithelial compartment. This 'thicket' mesh work of adherent gel physically protects underlying cells from harm. Beneath their membrane attachments, the most proximal ends of transmembrane mucin are intracellular (cytosolic) components that can be prompted (by extracellular events) to detach and be involved in intracellular signaling pathways that regulate inflammation, differentiation, apoptosis and cell-cell interactions (18).

Distributed within both soluble and adherent mucus layers of the GIT are three families of trefoil factors: TFF1, TFF2 and TFF3 (19). Trefoil peptides share a 40-aminoacid sequence shaped as a three-leaf clover of covalent loops (trefoil domain) stabilized through three internal disulfide bonds between six cysteine (nonessential) amino acids, rendering trefoils resistant to degradation by protease, acid or heat. TFF1 and TFF3 contain a single trefoil domain, while TFF2 has two. But differing from TFF2, TFF1 and TFF3 have a free cysteine residue in their C-terminal used to form covalent dimers with other TFF peptides or cysteine rich domains of mucins, which in turn aggregate in multimeric fashion. TFF3 is expressed in salivary glands of the oral cavity (swallowed to coat the esophagus) and predominant in goblet cells of the small intestine and colon. TFF1 and TFF2 are expressed on surface epithelial cells of the esophagus (which also benefit from a coating of salivary-derived TFF3), of the stomach (foveolar cells for TFF1), small intestine and colon. TFF3 secreted from goblet cells have been shown to form multivalent complexes and cross-linked lattices with transmembrane mucins $(20,21)$. Obviously, trefoil complexation with any of the seven transmembrane mucins may conceivably endow the mucin layer with a biophysically active role in intracellular signaling pathways modulating inflammation, apoptosis, differentiation and cell-cell interactions (12).

Trefoil factors are distributed along the enteric epithelium within the adherent and soluble mucus gel. When biophysically triggered to do so, mucin-embedded trefoil factors direct epithelial migration above the basement membrane of damaged or denuded epithelium $(22,23)$. This mucin-compartment process is known as epithelial restitution. Trefoil-driven restitution is the first elemental step to restore barrier integrity and is generally completed within 10-30 minutes of injury (24). Thus it can be imagined that concentrations of trefoil factor supplied to mucin layers by oral salivary glands and by epithelial and goblet cells of esophagus, stomach and colon are maintained at constitutive concentrations so that, if needed, can be locally augmented through feedback control (e.g., cytosolic or nuclear pathways) to ramp up local production of trefoil factors for the purpose of maintaining mucosal integritythat is, rapid epithelial restitution. Barrier therapies that enhance the structural integrity of the mucin gel can secondarily participate in these on-going inherent processes by supporting the structural biophysics required for normal function within the compartment.

\section{The epithelial compartment-multiple differentiated cell types}

The epithelial compartment is just as busy as the mucin compartment. It is composed of tightly joined single-cell layer of physical border cells within the mucosa of the oropharynx and extending throughout the GIT $(1,27,37,38)$. The epithelial compartment accommodates a range of surveillance cells that are regionally specialized throughout the GIT but invariantly populated by cells that are either fixed in place [epithelial cells, intra-epithelial lymphocytes 
(IEL), microfold or M-cells, goblet cells] $(25,28-30)$ or roaming just beneath the epithelium to conduct transepithelial sampling (dendritic cells) acting in coordination with M-cells, epithelial cells, IEL or goblet cells $(5,31,45)$. Each cellular component of the epithelial compartment not only physically exclude luminal contents, they are engaged in surveillance and sampling of luminal contents, and at times utilizes paracrine-controlled endocytosis of antigenic material. Also, within the epithelial compartment are chemosensory tuft cells (32) and secretory effector cells known as enteroendocrine cells (33).

While comprising only a minority of cells within the epithelial compartment, tuft cells and enteroendocrine cells functionalizes the epithelium with abilities to sense non-cellular antigens, toxins or particles and respond by secreting regulatory factors targeting other effector cells and elements. Tuft cells are major epithelial source of secreted interleukin 25 (IL-25) (34) which induces nuclear factor kappa light chain-enhancer of activated B-cells (NF$\kappa \mathrm{B}$ ), stimulates the production of IL-8 (a major chemotactic substance of neutrophils) and triggers involvement of $\mathrm{T}$ helper cell 17 (Th17) adaptive immune response (inducing IL-17), and involvement of Th2 adaptive immune response, inducing the secretion of IL-4, IL-5 and IL-13 (72). Enteroendocrine cells secrete gastric inhibitory peptide (GIP), glucagon-like peptide (GLP), vasoactive intestinal peptide (VIP) and serotonin $(33,35,36)$ all of which modulate digestion and can participate in mucosal immunoprotection.

\section{The lamina propria, submucosa and neurons}

Beneath the mucin and epithelial compartments lies the lamina propria and submucosal space populated by a host of immune cells regionally specialized throughout the GIT as well as a system of afferent and efferent neurons. Each of these elements-cellular and neuronal-has outgoing communications to respective targeted elements located outside the GIT. Through these lamina proprial and submucosal compartmental components the host is connected to the integrity of the mucosal barrier.

Firstly, the lamina propria harbors differentiated classes of cells for innate (pre-emptive) immunity $(11,46)$ and for adaptive (reactionary) immunity $(47,48)$. Myovascular components of the lamina propria are innervated by afferent and efferent fibers of enteric glial cells, a second major elemental class of this compartment.

Enteric glial cells (50-52) are functionalized by two principal types of receptors that are voltage-gated (53-55); that is, a flux exchange of ions across the receptors are required to turn on or turn off signaling. These receptors sense acid, chemical burn, pressure, mechanical stretch and pain. Effector neurofibers (including submucosal secretory neurons) not only generate nausea, secretions or paracrine cytokines, but also descend from the mucosal surface $(56,57)$ through the mucosal muscularis into the submucosal plexus and extending from there into the myenteric plexus to innervate proximally situated circular muscles and distally located (and externally situated) longitudinal muscles.

Table 3 summarizes structural neuronal elements while Table 4 summarizes mediators used for the maintenance, digestive functions, surveillance and defense of the GIT. Both Tables 3,4 show how inter-compartmental relationships are facilitated through receptors expressed on structural elements and how relationships are maintained by humoral mediators across compartments to register sensations (nociception, pressure, stretch, toxin), to actuate digestion, and to perpetuate motility and peristalsis.

Numerous receptors for epithelial and sub-epithelial neurons (receiving luminal stimuli vetted by an intact mucus gel) permit analysis and response to luminal contents as well as regulate intestinal motility, blood flow and conditions of algesia and other afferent sensations. Tables 3,4 summarizes the work of Holzer et al. (58-60), of others investigating the role of sensory neurons in enteric function and dysfunction (51,61-64) and of researchers studying growth factors in the maintenance of enteric function and mucosal integrity (39-42,73). Upregulated by nearby immune cells (and/or luminal contents), afferent and efferent neurons facilitate peristalsis as well as symptoms of colic, spasm, ileus, nausea, vomiting and diarrhea $(52,74)$. These symptoms both warn the host of harm as well as address the offending luminal agent.

\section{The dynamism of a bealthy biological barrier}

A narrative on the structure of a healthy mucosal barrier can be one dimensional. Cross-sectional perspective of a healthy mucosal barrier is multidimensional and depicts the dynamism of the mucosal barrier targeted by barrier therapies. Rather than simply viewed as a physical and functional partition passively separating host tissue from luminal contents (as discussed earlier), the mucosal barrier is active and dynamic. Its dynamism maintains overall health of organ lined by the mucosal barrier. In the GIT, structural elements with specific functions not 
Table 3 Structural neuronal receptors stimulated by luminal contents for sensory, motility \& blood flow

Epithelial receptors near mucous gel layer

$$
\begin{aligned}
& \text { A. For nociception } \\
& \text { Acid-sensing ion channels ( } 5 \text { types) } \\
& \text { Orphan G-protein coupled receptor (50 types) } \\
& \text { Mechanosensitive } \mathrm{K}+, \mathrm{Ca} 2+\text { channels } \\
& \text { Transient receptor potential (2 types) } \\
& \text { Ionotropic P2X purinoceptors ( } 4 \text { types) } \\
& \text { Epithelial \& sub-epithelial receptors }
\end{aligned}
$$

$$
\begin{aligned}
& \text { A. For digestive \& peristaltic physiology } \\
& \text { 5-HT receptors (7 types) } \\
& \text { Cholecystokinin CCK receptors } \\
& \text { Somatostatin SST receptors } \\
& \text { Mechanosensitive K+, Ca2+ channels } \\
& \text { Corticotropin-releasing factor receptor } \\
& \text { Adenosine receptors (2 types) } \\
& \text { B. For neurons }
\end{aligned}
$$

Neurotrophic receptors

Protease-activated receptors (2 types)

Voltage-gated $\mathrm{Ca} 2+$ channels

Voltage-gated $\mathrm{K}+$ channels

Tetrodotoxin-resistant $\mathrm{Na}+$ channels

Voltage-gated $\mathrm{Ca} 2+$ channels

Voltage-gated K+ channels

Epithelial \& subepithelial receptors

C. For analgesia, motility, blood flow

Bradykinin Receptors (2 types)

Tachykinin receptors (3 types)

Calcium-gene related peptide receptors

Prostaglandin receptors (4 types)

Cannabinoid CB1 receptors

Opioid receptors-(3 types: $m, k, d)$

lonotropic \& metabotropic glutamate receptors (IMGR)

Arranged by Translational Medicine Clinic and Research Center Storrs (c) 2006.
Table 4 Humoral mediators for GI maintenance, surveillance \& defense

Within the mucous gel layer

IgA, trefoil factors, Reglll- $\gamma$, CLCA1, Agr2, RELM- $\beta$, Zg16, sPLA2, cathelicidins, $\alpha$-defensins, lysozyme, $\beta$-defensins

Within the submucosal plexus layer

A. For the mucosa muscularis

ChAT, Tk, calbindin

B. For cholinergic vasodilatation

ChAT, calrentin, DYN, NYP

CCK, SOM, CGRP

C. For non-cholinergic vasodilatation

VIP, GAL

D. Within the intrinsic primary afferent neuron (IPAN)

ChAT, Tk, calbindin

E. Pro- \& anti-inflammatory analgesia cytokines/mitogens

NGF, FGF, TGF, prostaglandins, histamines, thrombin

Within the myenteric plexus layer

A. For the longitudinal muscle

ChAT, TK, calretinin GAL

B. For the circular muscle

ChAT, Tk, NOS, VIP, ATP

Enk, GABA, NFP, NPY

Pacap, DYN, GRP

C. For the plexus ganglia

ChAT, ATP, 5-HT, NOS, VIP, GRP, NPY, SOM

D. Within the intrinsic primary afferent neuron (IPAN)

ChAT, Tk, calbindin

E. Within the intestinofugal sympathetic ganglia

ChAT, GRP, VIP, CCK, Enk

Arranged by Translational Medicine Clinic and Research Center Storrs (C) 2006. Agr2, anterior gradient-2; ATP, adenosine triphosphate; CCK, cholecystokinin; ChAT, choline acetyltransferase; CLCA1, chloride channel accessory-1 protein; DYN, dynorphin; Enk, enkephalin; FGF, fibroblast growth factor; GABA, gamma-aminobutyric acid; GAL, galanin; GRP-gastrin releasing peptide; 5-HT, serotonin; IgA, immunoglobulin-A; NFP, neurofilament protein; NGF, nerve growth factor; NOS, nitric oxide synthase; NPY, neuropeptide-Y; PACAP, pituitary adenylate cyclase-activating peptide; Reglll- $\gamma$, regenerating islet-derived protein-3 gamma ; RELM- $\beta$, resistin-like molecule beta; SOM, somatostatin; sPLA2, secretory phospholipase type A-2; TGF, transforming growth factor; TK, tachykinins; VIP, vasoactive intestinal peptide; Zg16, zymogen granule membrane protein-16. 
only perform baseline deliberative deeds of digestion, they also are obliged to simultaneously surveil and reflexively address unexpected threats. Thus, the interplay between baseline surveillance, antigen/toxin analysis and reflexive and/or defensive actions defines the dynamism of a healthy biological barrier, and this dynamism is protected by a mucus gel bilayer that must remain structurally and functional unperturbed. The system of barrier control is focal, local and decentralized. Yet, when challenged by unfamiliar or intrusive luminal agents, all control can be rapidly integrated and amalgamated to maintain uninterrupted separation of luminal contents from the body's internal milieu. It is a dynamic autocrine and paracrine-driven coordination accomplishing the goals of digestion while simultaneously sifting through unfamiliar antigens, classifying them as 'friend or foe' and then addressing the threat efficiently. Functional integrity of the mucus gel supports the barrier's multiplex of obligatory processes and allows them to proceed smoothly. An intact mucus gel is the zone of interface coordinating with epithelial and subepithelial elements to assess antigens. It is ground zero where responses to threats are delivered, these responses having been pre-packaged in the epithelium and subepithelium and delivered to the mucin gel compartment to execute the response formed in underlying epithelial and subepithelial compartments. This hidden unending multiplexed operation proceeds beneath the continuous structural integrity of the mucin compartment (5). The mucin gel compartment is where intelligence is gathered from the lumen, passed on to decipherers below and where pre-packaged responses to threats are in turn received to neutralize them and eventually eliminate neutralized threats with a steady sloughing flow of soluble mucus gel.

As stated earlier, GIT function is a dynamic autocrine and paracrine-driven coordination (49) maintained beneath an operationally active mucin gel that must itself remain structurally and functionally unperturbed. Thus the dynamism of the mucosal barrier can be best understood from the following narrative of a cross-sectional view of the GIT.

\section{Cross-sectional perspective from pre-epithelium to epithelium}

Events occurring within the two mucin layers impact the GIT, from the luminal surface down to the single-cell epithelial layer comprised of eight cell types (epithelial, IEL, IEL, goblet, paneth, microfold, tuft, EEC), then deeper to the subepithelial lamina propria and deeper still to subserosal longitudinal muscles. Signaling information and events emanating from the mucus gel travels cross-sectionally from the lumen through mucin, epithelium, lamina propria on to the subserosa. Effective barrier therapies meaningfully engage the mucin gel to secondarily and indirectly, quell clinical symptoms and signs of a disrupted mucin compartment. Clinical symptoms and signs of the GIT (and too, of the labia and oropharynx) are cross-sectional reactions mounted by cellular elements within layered compartments far beneath any breach in the mucus gel at the luminal surface. Specifically, luminal contents can influence and activate inter-compartmental communications (75), but these communications are under vigilant control of epithelial nuclei working subsectionally within the GIT to grossly maintain homeostasis (43). Epithelial nuclei maintain smooth operational control that directs sifting of luminal contents, deciphering friend from foe, neutralizing threats by defensive actions of the epithelial cell, or of innate and/ or adaptive immune cells. This ongoing 'police action' transpires seamlessly and simultaneously with the primary purpose of the epithelium to digest nutrients according to its regional location within the GIT.

The epithelial layer, often relegated as an inanimate 'skeleton' of the mucosal barrier, is perpetually dynamic. The apical and basolateral membranes of the epithelial cell are functionalized. Besides portals for nutrient metabolism and transport, the apical surface of the epithelial abutting the mucin compartment has pattern-recognition receptors (toll-like receptors, Nod-like receptors, Rig-I like receptors) that detect common microbial ligands (44) as well as transmembrane mucins that form glycocalyx extensions interwoven like 'dreadlocks' into the adherent mucus gel, constructing an exclusionary electrostatic biophysical 'thicket' capable of measured engagement of luminal contents. On the basolateral surface of enteric epithelium are reservoirs of growth factors and additional receptors that are modulated by cytokines expressed from innate or adaptive immune cells residing in the underlying lamina propria. Yet in itself, when prompted, epithelial cells can elaborate cytokines to direct focal actions of underlying (upregulated) innate and adaptive immune cells (7).

Further accessorizing the epithelium is a neighboring collection of intra-epithelial cells tasked with sampling, assessing and presenting antigens. These are dendriteassociated goblet cells, microfold cells (M-cells) and both types of IEL ( $\alpha \beta$-IEL's \& $\delta \gamma$-IEL's). Additional neighbors interspersed within the epithelium are chemosensory tuft cells and serotonin-rich enteroendocrine cells, both of 
which augment the epithelium with supplementary sensory and effector functions. Submucosal part of the mucosal barrier is populated by effector cells of the innate and adaptive immune system which when prompted actively produce innate or adaptive immune responses to mount offensives against luminal assailants that target mucus, the epithelium or the submucosa. These immune cells may be free range or grouped in submucosal "police sub-stations", known as mucosal associated lymphoid tissue (MALT) and as Peyer's patches.

Neurons make the barrier alive. Reacting to cytokines elaborated by cellular elements of the epithelial comparment and innate or adaptive immune system, enteric neurons associated with the mucus gel-epithelial interface enable vascular, muscular and other immune elements beneath the epithelium to react and respond.

\section{Cross-sectional perspective from lamina propria to subserosal musculature}

Coursing from epithelium through the lamina propria are afferent neurons furnished with voltage gated receptors [acid sensing ion channels (ASIC) and the transient receptor potential vanilloid (TRPV) receptors] $(53,54)$, receiving serotonin signals from enteroendocrine cells and transmitting them through the mucosal muscularis into the submucosal plexus where signals trifurcate (56). Trifurcated signals can go (I) to secretory neurons that project fibers back up into the lamina propria to release acetylcholine (Ach) and VIP at the basolateral surface of the epithelium, (II) to vasomotor neurons of the lamina propria that innervate blood vessels, or (III) downward through fibers of intrinsic primary afferent neurons (IPAN) which in turn pierce through the circular muscle into the myenteric plexus. Here the IPAN cell bodies are grouped with cell bodies of excitatory and inhibitory motor neurons (IMN) which in turn, are distributed throughout the myenteric plexus. Within the myenteric plexus Ach-communication from IPAN cell bodies to the IMN which secrete nitrous oxide (NO), VIP, and betanicotinamide adenine dinucleotide $(\beta-\mathrm{NAD})$ can directly stimulate IMN innervations of circular muscle or drive the antecedent signal through descending interneurons (DIN) to indirectly stimulate IMN innervations of longitudinal muscles. Similarly, Ach-communication from IPAN to excitatory motor neurons (EMN) [which secrete Ach and substance-P (SP)] can directly signal EMN innervation of circular muscle or indirectly use DIN to signal EMN innervations of longitudinal muscles (56). Along the way, neurons and glial cell bodies are targeted by any number of cells from both the innate and adaptive immune system thus modulating luminally derived input as it courses from the epithelium downward through the submucosa and on to the circular and longitudinal muscles (65). This type of layered modulation permit a finely coordinated granular response to luminal stimuli that has been vetted through a structurally intact mucin gel compartment.

Besides voltage-gated ASIC and TRPV nociceptors, mucosal neurons express receptors for serotonin, histamine, prostaglandin 2, IL-1 $\beta$, TNF, IL-6, IL-17A as well as pathogen-recognition receptors (PRRs), e.g., TLR's. Alternatively, enteric neurons upregulated by untoward luminal agents secrete calcitonin gene-related peptide (CGRP), SP, VIP, somatostatin and galanin to directly modulate mast cells, neutrophils, T-cells and macrophages.

\section{Integrity monitored at the interface of the apical epithelium and mucus gel}

Corporeal integrity of the mucosal barrier rests with epithelial cells structurally fitted with apical transmembrane mucins that are interwoven and fasten to adherent mucus gel at cysteine-rich midpoints of MUC2 mucin strands (18).

Globlet cell derived trefoil factors are induced by nearby epithelial enterocytes with apically supported transmembrane mucin. Multimeric complexation of trefoil factors with glycocalyx of transmembrane mucin act as 'antennae stabilizers' of transmembrane mucin. Any significant biophysical alteration of the trefoil-stabilized glycocalyx can possibly trigger detachment of cytosolic sections of transmembrane mucin. Detached cytosolic sections may then participate in signaling pathways that modulate the transcription of pro-inflammatory and anti-inflammatory effector molecules (e.g., NF-кB). The type, extent and quality of cytosol signaling will vary in accordance to the type of transmembrane mucin involved (MUC1, 3, 4, 12, 13,16 or 17). Effective barrier therapies physically engage the mucin compartment to support biophysical stability of trefoil-stablized transmembrane mucin. This in turn provides uninterrupted continuity of structural and functional integrity within the mucin compartment and thereby protecting homeostatic processes in compartments beneath it.

\section{Assessing barrier therapies}

\section{Why they work}

The homeostatic dynamism of the mucosal barrier is 
Table 5 Common clinical standard of fitness for mucosal barrier therapies

\begin{tabular}{ll}
\hline Characteristic & Description \\
\hline 1 & Safe, biocompatible and effective \\
2 & $\begin{array}{l}\text { Provide physical support that is physiologically } \\
\text { relevant to mucosal integrity }\end{array}$ \\
3 & Acts locally and non-systemic \\
4 & Distal exit of body cavity into which it was \\
& introduced \\
5 & Exit chemically unchanged from the body \\
\hline
\end{tabular}

maintained by the physical and functional integrity of mucin compartment. Both mucus gel layers guard subordinate compartments, their respective cellular elements and their compartment-specific signaling and humoral communications among their cellular and structural components. Thus, all things being equal, the overall integrity of the mucosal barrier rests within the mucin compartment which must remain functionally and structurally unperturbed (12). Barrier therapies work because they are designed to restore and protect the physical integrity to the mucus gel layer, which is a decisive action in managing certain clinical syndromes characterized by physical disruption of the mucosa. In such situations, effective barrier therapies efficiently engage mucin, which when restored, resumes defense of processes and functions of the underlying compartments (12). As a result, the complex of cells and their respective signaling and humoral elements scattered across three histological compartments are then kept intact. So, despite the fact that mucosal functions are interrelated and integrated, continuous operation of those functions are preserved by the physical and operational integrity of the adherent and soluble mucus gels of the mucin compartment (12). Barrier therapies work to maintain physical integrity of the mucin compartment.

Effective engagement of a compromised mucin compartment is why barrier therapies work. The application of such therapies at the luminal surface must be biophysically sufficient to enable the mucin compartment to either prevent mucosal inflammation, facilitate mucosal restoration or both.

\section{Common clinical standard of fitness for mucosal barrier therapies}

At least five characteristics or traits define a common clinical standard of fitness for any barrier therapy and is shown in
Table 5. All therapies with CE marks or US FDA 510k license should have many of these characteristics which support some assessable measure of clinical fitness. Few have all five. Nonclassical barrier therapies will have 3 of five characteristics while classical barriers therapies will have all five.

The first common clinical standard of fitness for a mucosal BT is that it is, safe, biocompatible and effective. Secondly, a BT should provide physical support by means that are physiologically relevant to mucosal barrier function. That is, it should have a mechanism of action that is biophysically relevant in restoring integrity to a compromised mucosa. Third, a BT should act locally and non-systemically. It should not require processing by the body to be clinically effective. Fourthly, a BT should exit the body cavity at some point distal to the area of introduction or application. Fifth, upon exiting the body, a BT should be substantially intact, chemically unchanged and present in amounts substantially equal to the administered dose.

While there may be additional characteristics, these five provide a minimal clinical standard of fitness by which commercial barrier therapies can be assessed. Barrier therapies that substantially dissemble, that are significantly absorbed from the lumen and that are irretrievable in amounts similar to the original dose likely utilized a drug or chemical mechanism of action to achieve their intended clinical effect. Barrier therapies are to be therapies that provide or promote barrier integrity by a mechanism that is physically relevant to the biology of the mucosal barrier. In other words, the physical mechanism of action should be physiologically relevant to physical components of the mucosa. Mucosal components should be accessible for dose application from the lumen. It is envisaged that barrier therapies have a system of physical application by swabbing, spraying, dabbing, swallowing or enema.

\section{Commercial mucosal barrier therapies}

Table 5 lists barrier therapies currently authorized as medical devices in the US and EU. As can be seen there are 16 branded mucosal barrier therapies comprised of nine distinct compositional formulas targeting clinical syndromes in eight anatomical sites from the labial mucosa to colonic mucosa.

Four of these therapies have both US FDA 510k license and CE mark (Episil ${ }^{\circledR}$, Caphosol $^{\circledR}$, Gelclair $^{\circledR}$, MuGard $^{\circledR}$ ) which attenuate pain of oral mucositis each containing different components. Five therapies are CE-marked only-ViruProtect ${ }^{\circledR}$, Ziverel $^{\circledR}$, Esoxx ${ }^{\circledR}$, Gelenterum $^{\circledR}$ 
Table 6 Authorized barrier therapies-CE mark \& FDA 510k license

\begin{tabular}{|c|c|c|c|c|c|}
\hline Organ & Clinical syndrome & Trade name & US FDA registration & CE mark & Composition \\
\hline Labia & Aphthous ulcer & Orafate $^{\circledR}$ & US FDA 510k Class II & Pending Class II & Polymerized sucralfate gel \\
\hline Gingiva & $\begin{array}{l}\text { Gingivitis; } \\
\text { periodontitis; implant } \\
\text { mucositis }\end{array}$ & Orafate $^{\circledR}$ & US FDA 510k Class II & Pending Class II & Polymerized sucralfate gel \\
\hline Oral palate & Lichen planus & Orafate $^{\circledR}$ & US FDA 510k Class II & Pending Class II & Polymerized sucralfate gel \\
\hline Oropharynx & Pharyngitis & ViruProtect $^{\circledR}$ & None & CE mark Class II & Glycerin trypsin \\
\hline Oropharynx & Ulcerative mucositis & ProThelial $^{\circledR}$ & US FDA 510k Class II & Pending Class II & Polymerized sucralfate paste \\
\hline Oropharynx & Oral mucositis pain & Episil $^{\circledR}$ & US FDA 510k Class I & CE mark Class I & $\begin{array}{l}\text { Glycerol dioleate, soy } \\
\text { phosphatidyl choline, propylene } \\
\text { glycol, polysorbate } 80 \text {, ethanol }\end{array}$ \\
\hline Oropharynx & Oral mucositis pain & Caphosol $^{\circledR}$ & US FDA 510k Class I & CE mark Class I & $\begin{array}{l}\text { Disodium \& monosodium } \\
\text { phosphate, calcium and sodium } \\
\text { chloride }\end{array}$ \\
\hline Oropharynx & Oral mucositis pain & Gelclair $^{\circledR}$ & US FDA 510k Class I & CE mark Class I & $\begin{array}{l}\text { Hyaluronate, polyvinylpyrrolidone, } \\
\text { propylene glycol, PEG- } \\
40 \text {, hydroxyethylcellulose, } \\
\text { hydrogenated castor oil }\end{array}$ \\
\hline Oropharynx & Oral mucositis pain & MuGard $^{\circledR}$ & US FDA 510k Class I & CE mark Class I & $\begin{array}{l}\text { Carbomer, homopolymer a, } \\
\text { polysorbate } 60, \text { phosphoric acid, } \\
\text { benzyl alcohol, glycerin, citrate }\end{array}$ \\
\hline Esophagus & GERD, NERD & Ziverel $^{\circledast}$ & None & CE mark Class III & $\begin{array}{l}\text { Hyaluronate/chondroitin sulfate, } \\
\text { poloxamer } 407\end{array}$ \\
\hline Esophagus & GERD, NERD & Esoxx $^{\circledR}$ & None & CE mark Class III & $\begin{array}{l}\text { Hyaluronate/chondroitin sulfate, } \\
\text { poloxamer } 407\end{array}$ \\
\hline Esophagus & Ulcerative mucositis & ProThelial $^{\circledR}$ & US FDA 510k & Pending Class III & Polymerized sucralfate paste \\
\hline Gastroesophageal & GERD & Gaviscon $^{\circledR}$ & US FDA monograph & None & Alginate \\
\hline Gastroesophageal & GERD, NERD & Esolgafate $^{\mathrm{TM}}$ & None & Pending Class III & $\begin{array}{l}\text { Polymerized sucralfate } \\
\text { suspension }\end{array}$ \\
\hline Small intestine & Chemo-mucositis & ProThelial $^{\circledR}$ & None & Pending Class III & Polymerized sucralfate paste \\
\hline Colon & $\begin{array}{l}\text { Irritable bowel } \\
\text { syndrome }\end{array}$ & Enterofate $^{\circledR}$ & None & Pending Class III & Polymerized sucralfate capsule \\
\hline Colon & Diarrhea & Gelenterum $^{\circledast}$ & None & CE mark Class III & Gelatin tannic acid \\
\hline Colon & Diarrhea & $\operatorname{Tasectan}^{\circledR}$ & None & CE mark Class III & Gelatin tannic acid \\
\hline Colon & Radiation proctitis & ProctiGard $^{\circledR}$ & US FDA 510k Class II & None & $\begin{array}{l}\text { Carbomer, homopolymer a, } \\
\text { polysorbate } 60 \text {, phosphoric acid, } \\
\text { benzyl alcohol, glycerin, citrate }\end{array}$ \\
\hline Colon & Radiation proctitis & Colofate $\mathrm{TM}^{\mathrm{TM}}$ & None & Pending Class III & Polymerized sucralfate enema \\
\hline Colon & Ulcerative colitis & Colofate $^{\mathrm{TM}}$ & None & Pending Class III & Polymerized sucralfate enema \\
\hline Colon & Pouchitis & Colofate $^{\mathrm{TM}}$ & None & Pending Class III & Polymerized sucralfate enema \\
\hline
\end{tabular}

GERD, gastroesophageal reflux disease; NERD, non-erosive reflux disease. 
and Tasectan ${ }^{\circledR}$. Respectively, one is for viral pharyngitis containing glycerin and trypsin, another two are for esophageal heartburn pain containing poloxamer 407 with hyaluronate and chondroitin sulfate, and the last two are for colonic diarrhea containing gelatin tannate. ProctiGard ${ }^{\circledR}$, containing carbomer, homopolymer A, polysorbate 60 glycerin and phosphoric acid, has FDA 510k license but no CE mark and is prescribed for radiation proctitis. Each of the foregoing devices are non-classical barrier therapies due to the lack of having all five common traits for standard clinical fitness. In that respect, this class of barrier therapies differ from the following.

Gavison ${ }^{\circledR}$, Orafate ${ }^{\circledR}$, ProThelial ${ }^{\circledR}$, Esolgafate $^{\circledR}$, Enterofate $^{\circledR}$ and Colofate ${ }^{\circledR}$ are classical barrier therapies containing all five common traits for standard clinical fitness. Gaviscon ${ }^{\circledR}$ is complaint with US FDA OTC Monograph and registered in the EU as a heartburn therapy. It contains alginate which acts as a barrier to gastric acid in the distal esophagus. It is not CE marked.

The latter five therapies are compositionally similar. Each contains polymerized or polymeric cross-linked sucralfate, which is the non-drug active device form of sucralfate. Polymerized sucralfate occurs when non-polymerized sucralfate (in tablets, sachets or suspension) is exposed to gastric acid. Orafate and ProThelial are respectively gel and paste forms of polymerized sucralfate having US FDA 510k licenses and pending CE Mark applications. Esolgafate ${ }^{\circledR}$ is a suspension of polymerized sucralfate, Enterofate ${ }^{\circledR}$ is a capsule form of dried polymerized sucralfate and Colofate ${ }^{\circledR}$ is an enema solution of polymerized sucralfate. Each have pending CE mark applications, but neither has US FDA $510 \mathrm{k}$ licenses.

Of the nine compositionally distinct formulas listed in Table 6, only two satisfy the common clinical standard of fitness having all five traits. These two-alginate and polymerized sucralfate-are compositionally distinct. The remaining devices are non-classical barrier therapies possessing only two or three of five required traits of clinical fitness.

\section{Non-classical barrier therapies}

Non-classical barrier therapies for the GIT have two or three of the five characteristics that satisfy the common clinical standard of barrier fitness. Compositional formulations of these therapies include components that are substantially metabolized in the body, chemically changed and irretrievable in any substantial amounts from the distal end of the lumen to which they were introduced. However because some regulatory agencies do not consider that metabolism of components as required to achieve clinical effect, these therapies are regarded as medical devices. Drug effects can neither be proven or disproven; therefore, it is assumed that none exist.

However, a recent review of three CE marked mucosal barrier therapies (those containing glycerin trypsin, gelatin tannate and poloxamer 407 with hyaluronate chondroitin sulfate) raised a question as whether these CE marked medical devices were actually pharmacological agents (76). Examining package inserts, published trials, promotional claims and their compositional ingredients, Huijghebaert et al. (76) found that as to claimed mechanisms of action, none of the studies that supported CE mark authorization 'unambiguously conclusive'. Specifically, Huijghebaert et al. (76) pointed out that claimed film effects were never observed or visualized and the supposed barriers were on the wrong side (internal side) of the mucosa. Huijghebaert et al. pointed out that in experimental data that orally administered glycerin tannate blocked LPS toxins introduced by intraperitoneal (serosal) injection which can only gain access to the gut wall from the vascular compartment well beneath the lumen into which glycerin tannate had been applied. According to Huijghebaert et al. (76), animal models used to demonstrate barrier function for gelatin tannate exhibited a $\mathrm{pH}$ near the isoelectric point of gelatin ( $\mathrm{pH}$ 4.7). Barrier function could not be assured at $\mathrm{pH}$ range of human gut since gelatin tannate hydrolyzes above or below $\mathrm{pH}$ 4.7. Additionally, in the colon, where the gelatin tannate barrier is purportedly established to stop diarrhea, bacteria hydrolyzes both components of the device. These observations raise questions as to efficacy and physiological basis whereby the mucus gel is physically supported by gelantin tannate in the colon.

In discussing glycerin trypsin spray to treat or prevent rhinovirus sore throat infection Huijghebaert et al. (76) questioned its mechanism of action. The glycerin trypsin barrier sprayed on the pharynx supposedly intercept rhinovirus, however rhinovirus infects by nasal cavity or conjunctiva and not at the oropharyngeal cavity. It is indeed true that for clinical infection rhinovirus must be deposited on the nasal mucosa or conjunctiva and that oral inoculation is not sufficient to establish infection (77). This lack of physiologically relevant mechanism of action and the associated lack of clinical evidence caused national regulatory bodies to block distribution of glycerin trypsin in Germany (78).

As to poloxamer 407 and hyaluronate-chondroitin 


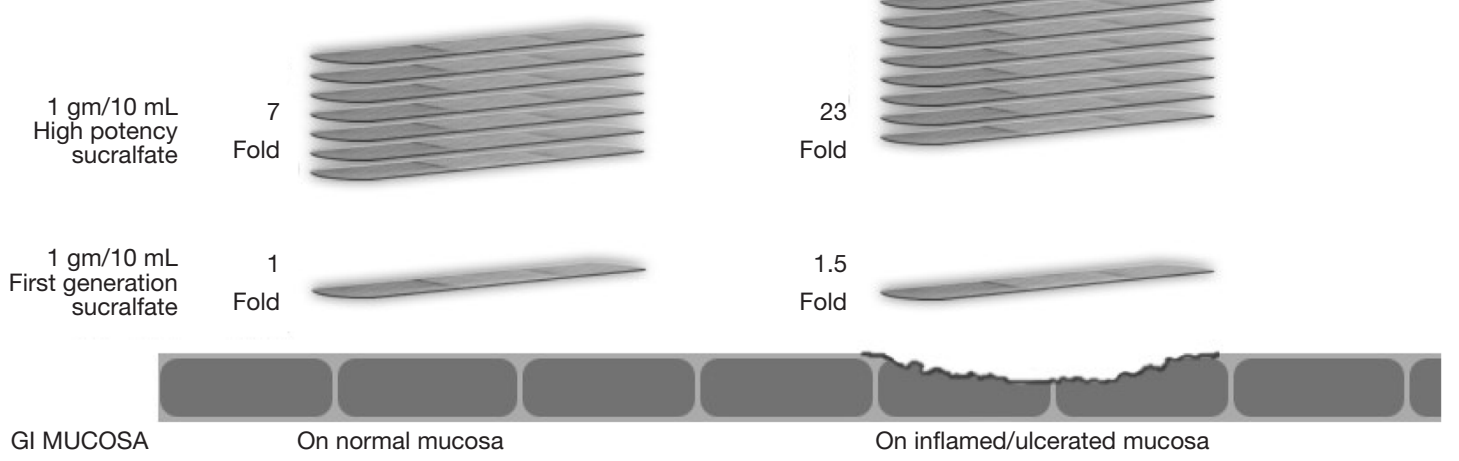

Figure 1 Exaggerated muco-adherence polymeric sucralfate-3 hours post-administration. Used by permission from Mueller Medical International (C) 2012.

sulphate suspensions for GERD, Huijghebaert et al. (76) raised the question as to sufficiency of poloxamer concentration in forming a film over the esophagus and gastric lining. Thermogelling of poloxamer 407 occurs at concentrations 10 -fold of that used in these medical device preparations, a fact which questions the claimed mechanism of action involving film formation over the esophagus.

\section{Classical barrier therapies}

Classical barrier therapies have all five characteristics satisfying the common clinical standard of barrier fitness. Alginate and polymerized-sucralfate are classic mucosal barrier therapies. Each is safe, biocompatible and proven clinically effective. Both provide physical support that is physiologically relevant to mucosal integrity. Each act locally, are non-systemic, exit the distal end of the body cavity into which they were introduced and do so chemically unchanged in amounts substantially equal to the dose administered.

Gaviscon ${ }^{\circledR}$ containing alginate was likely the first commercially available BT dating to 1960's (79) where it was consider a new principle approach to treat reflux esophagitis.

Polymerized sucralfate recognized by US FDA in 2005, is sucralfate-based BT. The original non-polymerized sucralfate was patented in the US in 1969 (80), then approved by US FDA in 1982 as a drug for the treatment of duodenal ulcers (81).

First commercialized under the trade name of Carafate ${ }^{\circledR}$, non-polymerized sucralfate is internationally ubiquitous, and has been regulated as a drug, as indeed it is. Nonpolymerized sucralfate is not the active treatment form of sucralfate, rather sucralfate polymerized by gastric acid, or polymerized sucralfate, is the active therapeutic form of sucralfate. Because non-polymerized sucralfate undergoes a chemical reaction within the GIT (being polymerized by gastric acid) following oral ingestion, it is considered by US FDA as a drug. So too, without exception, international regulatory bodies view non-polymerized sucralfate as a drug, a therapeutic medicinal that require chemical alteration within the body (namely polymerization by gastric acid) to become therapeutically active in the GIT. Inert sucralfate applied externally or to oral mucosal wounds is generally moistened by water and, has a $60-80 \%$ weight concentration of sucralfate. Water-moistened sucralfate is self-amalgamated and self-annealed, having undergone 'water-polymerization' process. However at present, nearly without exception non-polymerized is first ingested, secondly contacts hydrochloric acid of the stomach, then as acid-polymerized sucralfate is applied internally to GIT mucosal wounds. Polymerized sucralfate is safe, biocompatible and effective, with $98 \%$ of it recovered as 
sucralfate 24-48 hours later dependent of individual GI transient times. The remaining $2 \%$ is believed to be sucrose octasulfate and aluminum hydroxide as incomplete reactants that failed salt-complexation during sucralfate manufacture. Polymerized sucralfate is non-systemic. Toxicology and pharmakinetic studies performed on sucralfate in its 1982 NDA application (82) involved sucralfate that had been polymerized following exposure to gastric acid.

In 2005 the Center for Devices and Radiological Health (CDRH) of the US FDA recognized polymerized sucralfate as a device and not a drug. The decision resulted from a meeting with the Center for Drug Evaluation and Research (CDER) which regulates non-polymerized sucralfate. The CDER and CDRH jointly decided that sucralfate polymerized prior to application was not a drug, but rather a combination product medical device having purely a proven physical mechanism of action (82). Thus as to the verity of its regulatory status, polymerized sucralfate is a genuine BT.

It should be noted that early published endoscopic images of sucralfate in the GIT were images of sucralfate that had been polymerized by gastric hydrochloric acid. The physical mechanism of action attributed to nonpolymerized sucralfate stem from these in vivo images of sucralfate adherent to mucosa of the GIT. It must keep in mind that these images are of gastric-acid polymerized (GAP) sucralfate derived from the chemical action of hydrocholic acid upon sucralfate originally ingested in its inert non-polymerized (drug) form. Electron micrographs of GAP-sucralfate shows adherence to mucus and not to the epithelium directly. In fact, as required for effective barrier therapies of the GIT, sucralfate has been shown to preferentially engage mucin $(83,84)$. Both transmission electron micrographs and scanning electron micrographs demonstrate that when denuded epithelium is present, sucralfate is found bound to mucin gel and not to apical epithelium which visibly is available for binding (83). These micrographs can be viewed in Chapter 7 (pages 74 and 76-79) in Hollander and Tygat's edited book, Sucralfate: From Basic Science to the Bedside (83). Mucosal bound GAP-sucralfate is firmly adherent to mucin resisting casual manipulation by endoscopic probes (85).

Orafate ${ }^{\circledast}$ for oral \& dental epithelial disorders and ProThelial ${ }^{\circledR}$ for chemoradiation ulcerative mucositis were the first commercially available polymerized sucralfate in the US. The acid polymerization process used to create polymeric sucralfate in Orafate $^{\circledR}$, ProThelial $^{\circledR}$, Esolgafate $^{\mathrm{TM}}$, Enterofate ${ }^{\circledR}$ and Colofate ${ }^{\mathrm{TM}}$ creates a polymeric sucralfate that has a barrier effect on both normal and inflamed GIT mucosa. On normal mucosa, this barrier effect is 7 times greater than sucralfate polymerized by gastric acid and similarly is 24 times greater on ulcerated or inflamed GIT mucosa. Figure 1 illustrates the barrier effect differences between GAP sucralfate and polymeric sucralfate.

Given that the clinical effect of polymeric sucralfate is non-systemic, wholly dependent on surface concentration and is better than GAP sucralfate, then it stands to reason that significant clinical differences should be observed as well. It has been reported from a study listed in the Cochrane Central Register of Controlled Trials (86) that polymeric sucralfate in Esolgafate ${ }^{\mathrm{TM}}$ demonstrated a 7 -day $80 \%$ symptomatic relief and $83 \%$ healing of GERD erosions (87).

The best symptomatic relief of GERD from GAP sucralfate in the Cochrane database of 23 such studies (88) was that reported by Vermeijden et al. (89).

Vermeijden et al. (89) reported that GAPsucralfate required 56 days for $80 \%$ symptomatic relief with a healing rate of $68 \%$ in patients with GERD. For similar clinical condition, polymeric sucralfate (Esolgafate ${ }^{\mathrm{TM}}$ ) required only 7 days for $80 \%$ symptomatic relief with a healing rate of $83 \%$ (87). Polymeric sucralfate in Esolgafate required a total dose of 21 gram to achieve the same relief and better healing rates. This was in contrast to 224 grams of GAP-sucralfate required in the trial reported by Vermeijden et al. In other words, patients suffering from GERD required 1/10 the total dose of sucralfate and just over $10 \%$ of the time, to achieve comparable relief and better rates of healing if polymerized sucrafate from Esolgafate was used instead of GAP sucrafate. Stated differently, the barrier effect of polymeric sucralfate in Esolgafate demonstrated a $77.7 \%$ reduction in time to clinical effect, a difference achieved using 3 grams per day of polymeric sucralfate for 7 days compared to 4 grams per day of GAP-sucralfate for 56 days. Given that $1 / 10$ the dose of sucralfate is required using Esolgafate, there is the additional benefit of decreased exposure to aluminum present in all sucralfate products. For the clinical syndrome of heartburn due to erosive GERD, the clinical potency and added safety of the barrier function associated with polymeric sucralfate (Esolgafate) are obvious.

Additionally, in a 28-day double blinded randomized controlled trial, polymeric sucralfate suspension (Esolgafate) was found more effective than placebo in symptomatic treatment of GERD (87) and was associated with $86 \%$ 
healing rate. Finally, a similar 28-day study, polymeric sucralfate suspension (Esolgafate) was found more effective than placebo in symptomatic relief of NERD (87), a clinical outcome in NERD that is largely uncommon for any sucralfate-based product..

In the US, the use of polymeric sucralfate as a BT (ProThelial) to prevent and rapidly reverse chemoradiation mucositis is a new therapeutic option in oncology support. Published treatment effect sizes in outcome data and the low risk of bias (90) in the US Mucositis Registry has achieved a Category $1 \mathrm{~A}$ intervention status in accordance to evidence based medicine guidelines established by the Grading of Recommendations Assessment, Development and Evaluation (GRADE) Working Group and published in Journal of Clinical Epidemiology (91,92). Clinical efficacy of polymerized sucralfate for mucositis throughout the GIT (93) suggests that structural and functional breaches in the mucosa caused chemoradiation in the oropharynx is clinically indistinguishable from mucosal breaches in the esophagus, small bowel and colon caused by the same cancer regimen.

\section{Conclusions}

Barrier therapies are for management of clinical syndromes rising from a breach within the mucosal barrier. Aphthous ulcer, gingival infection, inflammation or wounds, sore throats, heartburn (dyspepsia), chemoradiation mucositis of the oropharynx, esophagus, small bowel and colon as well as ulcerative colitis and pouchitis are clinical syndromes involving physical and inflammatory compromise of the mucosal barrier. Barrier therapies are designed for these ailments.

Meaningful evaluation of effective barrier therapies is benefited by a structure-function narrative regarding the mucosa. A healthy mucosal barrier is best understood from a cross-sectional perspective (discussed earlier), from which it becomes obvious that intracellular and intercellular functions within the three mucosal compartments employ protected communication with and through an overlying lumen-facing mucin compartment. Inherently required of this compartment is a principle of continuous, undisrupted physical (structural) integrity and unperturbed functional operations. Thus, effectual elimination of physical and functional breaches within the mucus gel compartment is 'assignment No.1' for any effective BT. Lacking this capacity of course raises questions as to the quality of the BT.

The five characteristics of clinical barrier fitness listed in
Table 5 are a basic and practicable approach to distinguish physical BT's from drug therapies and to discern the presence of mixture of the two. BT claims of clinical efficacy must involve a clear physical basis of operation and one that is physiologically relevant to the biology of the mucosal barrier under treatment. Beyond safety, biocompatibility and efficacy, classical barrier therapies should demonstrate physical barrier protection through engagement with mucin or with denuded epithelium. This was the premise of observations made by Huijghebaert et al. (76). The clinical effect of a BT should stem from a purely physical event and provide effective restoration of mucosal breach. As a result there should be causal diminution of symptoms and signs created by the breach under treatment. Classical barrier therapies should have such a clinically observable outcome.

Among commercially available barrier therapies reviewed in this report many were non-classical, possessing perhaps 2 or 3 of five common characteristics of clinical fitness. Of course, neither a CE mark nor FDA 510k license guarantees therapeutic quality; rather these market authorizations speak broadly to the therapy's mechanism of action. But as pointed out earlier, for some therapies it is difficult to confirm the physical mechanism of action due to limited information critical to understanding the body's handling of ingredients identified as active ingredients by the barrier manufacturer. If therapy components leave the the targeted area of mucosa, then how long does the therapy provide a physical barrier at the target site and where do components go afterwards?

Alginate and polymeric sucralfate (sucralfate polymerized by acid during manufacturing prior to patient use), are classic barrier therapies, having all five common characteristics for clinical standard of fitness. Market authorization for alginate is in the form of an alginate antacid combination; thus, it is a combination drug (antacid)_device (alginate) BT. Published observational trial (79) and a randomized controlled trial, have reported alginate (94) effective for the management of heartburn, the symptomatic breach of the gastroesophageal mucosa. Polymeric sucralfate, another classic BT, has been similarly useful for GERD, NERD (87) and chemoradiation mucositis $(90,93)$.

Clearly where breached mucosal barriers give rise to unsettling symptoms and signs, therapies designed to effectively target the mucosal breach is logical. Therapies that soothe symptoms without physically addressing structural disruptions only temporize syndromes of mucosal 
breach. Some mucosal breaches, for example those caused by scheduled chemoradiation treatments, do not temporize very well. US insurance actuarial data reveals that at least 46,100 patients die prematurely due solely to chemoradiation mucosal breaches (95). Fortunately, for these situations in the US, there is now an effective BT that confronts the cause and closes the breach utilizing a mechanism of action that is physiologically relevant to the structural (that is, biophysical) integrity of the mucosal barrier. Biophysical integrity of the mucosal barrier, particularly in the mucin gel, assures functional integrity and healthy homeostasis within the biology of the mucosal barrier.

\section{Acknowledgments}

Funding: None.

\section{Footnote}

Provenance and Peer Review: This article was a free submission to the journal. The article has undergone external peer review.

Conflicts of Interest: The author has completed the ICMJE uniform disclosure form (available at http://dx.doi. org/10.21037/tgh.2020.02.02). Ricky McCullough reports being medical director of a company that owns technology that polymerizes sucralfate. The author has no conflicts of interest to declare.

Ethical Statement: The author is accountable for all aspects of the work in ensuring that questions related to the accuracy or integrity of any part of the work are appropriately investigated and resolved.

Open Access Statement: This is an Open Access article distributed in accordance with the Creative Commons Attribution-NonCommercial-NoDerivs 4.0 International License (CC BY-NC-ND 4.0), which permits the noncommercial replication and distribution of the article with the strict proviso that no changes or edits are made and the original work is properly cited (including links to both the formal publication through the relevant DOI and the license). See: https://creativecommons.org/licenses/by-nc-nd/4.0/.

\section{References}

1. France MM, Turner JR. The mucosal barrier at a glance. J
Cell Sci 2017;130:307-14.

2. Farquhar MG, Palade G. Junctional complexes in various epithelia. J Cell Biol 1963;17:375-412.

3. Rodgers LS, Beam MT, Anderson JM et al. Epithelial barrier assembly requires coordinated activity of multiple domains of the tight junction protein. J Cell Sci 2013;126:1565-75.

4. Johansson ME, Larsson JM, Hansson GC. The two mucus layers of colon are organized by the MUC2 mucin, whereas the outer layer is a legislator of host-microbial interactions. Proc Natl Acad Sci U S A 2011;108 Suppl 1:4659-65.

5. Pelaseyed T, Bergstrom JH, Gustafsson JK et al. The mucus and mucins of the goblet cells and enterocytes provide the first defense line of the gastrointestinal tract and interact with the immune system. Immunol Rev 2014;260:8-20.

6. Johansson ME, Phillipson M, Petersson J, et al. The inner of the two Muc2 mucin-dependent mucus layers in colon is devoid of bacteria. Proc Natl Acad Sci U S A 2008; 105:15064-9.

7. Saenz SA, Taylor BC, Artis D. Welcome to the neighborhood: epithelial cell-derived cytokines license innate and adaptive immune responses at mucosal sites. Immunol Rev 2008;226:172-90.

8. Peterson LW, Artis D. Intestinal epithelial cells: regulators of barrier function and immune homeostasis. Nat Rev Immunol 2014;14:141-53.

9. Lundqvist C, Baranov V, Hammarström S, et al. Intraepithelial lymphocytes. Evidence for regional specialization and extrathymic $\mathrm{T}$ cell maturation in the human gut epithelium. Int Immunol 1995;7:1473-87.

10. van Wijk F, Cheroutre H. Intestinal T cells: facing the mucosal immune dilemma woith synergy and diversity. Semin Immunol 2009;21:130-8.

11. Sonnenberg GF, Artis D. Innate lymphoid cells in the initiation, regulation and resolution of inflammation. Nat Med 2015;21:698-708.

12. Shan M, Gentile M, Yeiser JR et al. Mucus enhances gut homeostasis and oral tolerance by delivering immunoregulatory signals. Science 2013;342:447-53.

13. Liévin-Le Moal V, Servin AL. The front line of enteric host defense against unwelcome intrusion of harmful microorganisms: mucins, antimicrobial peptides, and microbiota. Clin Microbiol Rev 2006;19:315-37.

14. US Food and Drug Administration. What is a medical device? Available online: https://www.fda.gov/industry/ regulated-products/medical-device-overview\#What $\% 20$ 
is $\% 20 \mathrm{a} \% 20$ medical\%20device

15. European Medical Agency. Medical devices with an ancillary medicinal substance. Available online: https:// www.ema.europa.eu/en/human-regulatory/overview/ medical-devices\#medical-devices-with-an-ancillarymedicinal-substance-section

16. European Commission DG Health and Consumer. Directorate B, Unit B "Cosmetics and medical devices". Available online: http://www.lne-gmed.com/pdf/en/ annex9-directive-93-42-amended.pdf

17. Allaire JM, Crowley SM, Law HT, et al. The intestinal epithelium: central coordinator of mucosal immunity. Trends Immunol 2018;39:677-96.

18. van Putten JP, Strijbis K. Transmembrane mucins: signaling receptors at the intersection of inflammation and cancer, J Innate Immun 2017;9:281-99.

19. Aihara E, Engevik KA, Montrose MH. Trefoil factor peptides and gastrointestinal function. Annu Rev Physiol 2017;79:357-80.

20. Yu H, He Y, Zhang X, et al. The rat IgGFccBP and Muc2 C-terminal domains and TFF3 in two intestinal mucus layers bind together by covalent interaction. PLoS ONE 2011;6:e20334.

21. Hoffmann W. TFF2, a MUC6-binding lectin stabilizing the gastric mucus barrier and more (Review). Int J Oncol 2015;47:806-16.

22. Dignass A, Lynch-Devaney K, Kinbdon H, et al. Trefoil peptides promote epithelial migration through a transforming growth factor $\beta$-independent pathway. J Clin Invest 1994;94:376-83.

23. Iizuka M, Konno S. Wound healing of intestinal epithelial cells. World J Gastroenterol 2011;17:2161-71.

24. Wong WM, Playford RJ, Wright NA. Peptide gene expression in gastrointestinal mucosal ulceration: ordered sequence or redundancy? Gut 2000;46:286-92.

25. Salzman NH. Enteric defensins are essential regulators of intestinal microbial ecology. Nat Immunol 2010;11:76-83.

26. Atuma C, Strugala V, Allen A, et al. The adherent gastrointestinal mucus gel layer: thickness and physical state in vivo. Am J Physiol Gastrointest Liver Physiol 2001;280:G922-29.

27. Lundqvist C, Baranov V, Teglund S, et al. Cytokine profile and ultrastructure of intraepithelial gamma delta $\mathrm{T}$ cells in chronically inflamed human gingiva suggest a cytotoxic effector function. J Immunol 1994;153:2302-12.

28. Turner JR. Intestinal mucosal barrier function in health and disease. Nat Rev Immunol 2009;9:799-809.

29. Kunisawa J. Intra-epithelial lymphocytes: their shared and divergent immunological behaviors in the small and large intestine. Immunol Rev 2007; 215:136-53.

30. Kucharzik T, Lugering N, Rautenberg K, et al. Role of $M$ cells in intestinal barrier function. Ann NY Acad Sci 2000;915:171-83.

31. Stagg AJ, Hart AL, Knight SC, et al. The dendritic cell: its role in intestinal inflammation and relationship with gut bacteria. Gut 2003;52:1522-9.

32. Ting HA, von Moltke J. The immune function of Tuft cells at gut mucosal surfaces and beyond. J Immunol 2019;202:1321-9.

33. Worthington JJ. The intestinal immunoendocrine axis: novel cross-talk between enteroendocrine cells and the immune system during infection and inflammatory disease. Biochem Soc Trans 2015;43:727-33.

34. Gerbe F, Legraverend C, Jay P. The intestinal epithelium tuft cells: specification and function. Cell Mol Life Sci 2012;69:2907-17.

35. Moran GW, Leslie FC, Levison SE, et al. Enteroendocrine cells: neglected players in gastrointestinal disorders? Therap Adv Gastroenterol 2008;1:51-60.

36. Mawe GM, Hoffman JM. Serotonin signalling in the gut-functions, dysfunctions and therapeutic targets. Nat Rev Gastroenterol Hepatol 2013;10:473-86.

37. Groeger SE, Meyle J. Epithelial barrier and oral bacterial infection. Periodontol 2000 2015;69:46-67.

38. Wang SS, Tang YL, Pang X, et al. The maintenance of an oral epithelial barrier. Life Sci 2019;227:129-36.

39. Dignass AU, Tsunekawa S, Podolsky DK. Fibroblast growth factors modulate intestinal epithelial cell growth and migration. Gastroenterology 1994;106:1254-62.

40. Greenhalgh DG. The role of growth factors in wound healing. J Trauma 1996;41:159-67.

41. Westman J, Nilsson M, Ornitz DM, et al. Synthesis and fibroblast growth factor binding of oligo-saccharides related to heparin and heparin sulphate. J Carbohydrate Chem 1995;14:95-113.

42. Szabo S, Vincze A. Growth factors in ulcer healing: lessons from recent studies. J Physiol Paris. 2000;94:77-81.

43. Goto Y, Ivanov II. Intestinal epithelial cells as mediators of the communsal-host immune crosstalk Immunol Cell Biol 2013:91:204-14.

44. Lavelle EC, Murphy C, O'Neill LA, et al. The role of TLRs, NLRs, and RLRs in mucosal innate immunity and homeostasis. Mucosal Immunol 2010;3:17-28.

45. Banchereau J, Briere F, Caux C, et al. Immunobiology of dendritic cells. Annu Rev Immunol 2000;18:767-811.

46. Bostick JW, Zhou L. Innate lymphoid cells in intestinal 
immunity and inflammation. Cell Mol Life Sci 2016;73:237-52.

47. Khounlotham M, Kim W, Peatman E, et al. Compromised intestinal epithelial barrier induces adaptive immune compensation that protects from colitis. Immunity 2012;37:563-73.

48. Malik A, Thirumala-Devi K. Inflammasome activation and assembly at a glance. J Cell Sci 2017;130:3955-63.

49. Andrews C, McLean MH, Durum SK. Cytokine tuning of intestinal epithelial function. Front Immunol 2018;9:1270.

50. Yu YB, Li YQ. Enteric glial cells and their role in the intestinal epithelial barrier. World J Gastroenterol 2014;20:11273-80.

51. Furness JB, Kunze WA, Clerc N. Nutrient tasting and signaling mechanisms in the gut II. The intestine as a sensory organ: neural, endocrine, and immune responses. Am J Physiol 1999:277:G922-8.

52. Furness JB, Callaghan BP, Rivera LR, et al. The enteric nervous system and gastrointestinal innervation: integrated local and central control. Adv Exp Med Biol 2014;817:39-71.

53. Holzer P. Acid-sensitive ion channels and receptors. Handb Exp Pharmacol 2009;(194):283-332.

54. Holzer P. Transient receptor potential (TRP) channels as drug targets for diseases of the digestive system. Pharmacol Ther 2011;131:142-70.

55. Holzer P. Acid-sensing ion channels in gastrointestinal function. Neuropharmacology 2015;94:72-9.

56. Gershon MD. The second brain. New York: Harper Collins, 1998.

57. Rao M, Gershon MD. The bowel and beyond: the enteric nervous system in neurological disorders. Nat Rev Gastroenterol Hepatol 2016;13:517-28.

58. Holzer P, Michl T, Danzer M, et al. Surveillance of the gastrointestinal mucosa by sensory neurons. J Physiol Pharmacol 2001;52:505-21.

59. Holzer P. Local effector functions of capsaicin-sensitive sensory nerve endings: involvement of tachykinins, calcitonin gene-related peptide and other neuropeptides. Neuroscience 1988;24:739-68.

60. Holzer P. Peptidergic sensory neurons in the control of vascular functions: mechanisms and significance in the cutaneous and splanchnic vascular beds. Rev Physiol Biochem Pharmacol 1992;121:49-146.

61. Raybould HE. Does your gut taste? Sensory transduction in the gastrointestinal tract. News Physiol Sci 1998;13:275-80.

62. Vanner S, Surprenant A. Neural reflexes controlling intestinal microcirculation. Am J Physiol 1996;271:G223-30.

63. Holzer P, Barthó L. Sensory neurons in the intestine. In: Geppetti P, Holzer P. editors. Neurogenic inflammation. Boca Raton: CRC Press, 1996:153-67.

64. Maggi CA. Tachykinins and calcitonin gene-related peptide (CGRP) as co-transmitters released from peripheral endings of sensory nerves. Prog Neurobiol 1995;45:1-98.

65. Chavan SS, Pavlov VA, Tracey KJ. Mechanisms and therapeutic relevance of neuro-immune communication. Immunity 2017;46:927-42.

66. Lehr CM, Poelma FGJ, Junginger HE, et al. An estimate of turnover time of intestinal mucus gel layer in the rat in situ loop. Intl J Pharmaceutics 1991;70:235-40.

67. Rubinstein A, Tirosh B. Mucus gel thickness and turnover in the gastrointestinal tract of the rat: response to cholinergy stimulus and implication for mucoadhesion. Pharm Res 1994;11:794-9.

68. Johansson ME. Fast renewal of the distal colonic mucus layers by the surface goblet cells as measured by in vivo labeling of mucin glycoproteins. PLoS One 2012; 7:e41009.

69. Kararli TT. Comparison of the gastrointestinal anatomy, physiology, and biochemistry of humans and commonly used laboratory animals. Biopharm Drug Dispos 1995;16:351-80.

70. Powell DW. Ion and water transport in the intestine. In: Andreoli TE, Schultz SG, Fanestil DD, et al. editors. Physiology of Membrane Disorders. 2nd ed. New York: Plenum, 1987:559-96.

71. Lang T, Hansson GC, Samuelsson T. Gel-forming mucins appeared early in metazoan evolution. Proc Natl Acad Sci USA 2007;104:16209-14.

72. Fort MM, Cheung J, Yen D, et al. IL-25 induces IL-4, IL-5, and IL-13 and Th2-associated pathologies in vivo. Immunity 2001;15:985-95.

73. Szabo S, Hollander D. Pathways of gastrointestinal protection and repair: mechanisms of action of sucralfate. Am J Med 1989;86:23-31.

74. Mittal A, Sagi V, Gupta M, et al. Mast Cell neural interactions in health and disease. Front Cell Neurosci 2019;13:110.

75. Sommer F, Backhed F. The gut microbiota physiology. Nat Rev Microbiol 2013;11:227-38.

76. Huijghebaert S, DeBruyne P, Allegaert K, et al. Medical devices in EU claiming oropharyngeal or gastrointestinal barrier action: barrier products or hidden pharmacological agents? Belgian Week of Gastroenterology 2018:Abstract K03, 129-30. Available online: http://www.bwge.be/wp- 
content/themes/Evento/pdf/2018_BW_Abstracts.pdf

77. Pappas DE, Hendley JO. Rhinoviruses. In: Long SS, Prober CG, Fischer M. Principles and practice of pediatric infectious diseases. 5th edition. Philadelphia: Elsevier, 2018:1219-21.e1.

78. Lindberg F, Wachtmeister CJ. Enzymatica AB: appeal on Enzymatica's cold spray in Germany overruled. Available online: https://www.globenewswire.com/ news-release/2018/12/10/1664401/0/en/EnzymaticaAB-Appeal-on-Enzymatica-s-cold-spray-in-Germanyoverruled.html

79. Sandmark S, Zenk L. New principles in the treatment of reflux esophagitis in hiatus hernia. Svenska Lakartidn 1964;61:1940.

80. Nitta Y, Masaya K, Kawa-saki-shi N, et al. Dissacharide polysulfate aluminium compound and method. US Patent 3,432,489, 1969.

81. US Food and Drug Administration. Carafate (Sucralfate). 1982. Available online: https://www.accessdata.fda. gov/scripts/cder/daf/index.cfm? event=overview. process\&ApplNo=018333

82. Oshea S. Office of Combination Products. Request for Designation Sucralfate $\mathrm{HCl}$ Topical Paste. Available online: https://www.fda.gov/downloads/CombinationProducts/ Jurisdictional Information/RFDJurisdictional Decisions/ UCM113797.pdf

83. Morris GP. Binding of sucralfate to mucosal surface. In: Hollander D, Tytgat GNJ. editors. Sucralfate: from basic science to the bedside. Boston: Springer, 1995:71-82.

84. Cohen MM, Bowdler R, Gervais P, et al. Sucralfate protection of human gastric mucosa against acute ethanol injury. Gastroenterology 1989;96:292-8.

85. Tarnawski A, Hollander D, Stachura J, et al. Effect of sucralfate on the normal human gastric mucosa. Endoscopic, histologic, and ultrastructural assessment. Scand J Gastroenterol Suppl 1987;127:111-23.

86. Cochrane Library. Cochrane Central Register of Controlled Trials. Clinical efficacy of sucralfate in reflux oesophagitis. Available online: https://www. cochranelibrary.com/content? templateType=rela ted\&urlTitle=/central/doi/10.1002/central/CN$00187363 \&$ doi $=10.1002 /$ central/CN-00187363\&p_p_ id=scolariscontentdisplay_WAR_scolariscontentdisplay\&_ scolariscontentdisplay_WAR_scolariscontentdisplay_ action=related-content\&p_p_lifecycle $=0 \& p \_p \_$mode $=$view
\& type $=$ central\&contentLanguage $=$

87. McCullough RW. Mucosa-centric clinical effects of high potency sucralfate: 28 day $83 \%$ resolution of undifferentiated dyspepsia, 28 day $83 \%$ reversal of sign \& symptoms of co-morbid IBS and 1 week $80 \%$ healing of GERD erosions-results of two randomized clinical trials. Gastroenterol 2014;146: S-263, abstr Sa1325.

88. Khan M, Santana J, Donnellan C. Medical treatments in the short term management of reflux oesophagitis. Cochrane Database Syst Rev 2007;(2):CD003244.

89. Vermeijden JR, Tytgat GN, Schotborgh RH, et al. Combination therapy of sucralfate and ranitidine, compared with sucralfate monotherapy, in patients with peptic reflux esophagitis. Scand J Gastroenterol 1992;27:81-4.

90. McCullough RW. High potency polymerized crosslinked sucralfate (HPPCLS, ProThelial) for NCCN Category 2A Evaluation to Prevent and Rapidly Eliminate Chemoradiation toxic mucositis.eP255. Supp Care Cancer 2019;27:S124-5.

91. Guyatt GH, Oxman AD, Kunz R, et al. GRADE: what is "quality of evidence" and why is it important to clinicians? BMJ 2008;336:995-8.

92. Guyatt GH, Oxman AD, Sultan S, et al. GRADE guidelines: 9. Rating up the quality of evidence. J Clin Epidemiol 2011;64:1311-6.

93. McCullough RW. Practice insights on patient caremanagement overview for chemoradiation toxic mucositisguidelines, guideline-supported therapies and high potency polymerized cross-linked sucralfate (ProThelial). J Oncol Pharm Pract 2019;25:409-22.

94. Beeley M, Warner JO. Medical treatment of symptomatic hiatus hernia with low-density compounds (alginate). Curr Med Res Opin 1972;1:63-9.

95. McCullough RW. US oncology-wide incidence, duration, costs and deaths from chemoradiation mucositis and antimucositis therapy benefits. Future Oncol 2017;13:2823-52.

doi: $10.21037 / \operatorname{tgh} .2020 .02 .02$

Cite this article as: McCullough RW. Barrier therapies supporting the biology of the mucosal barrier-medical devices for common clinical mucosal disorders. Transl Gastroenterol Hepatol 2021;6:15. 